\title{
Pengaruh Faktor Pemilihan lokasi Terhadap Efektivitas Pasar PANGgungrejo
}

\author{
Yohanita Pudyas Siswantika \\ PROGRAM STUDI PERENCANAAN WILAYAH DAN KOTA, FAKULTAS TEKNIK \\ UNIVERSITAS SEBELAS MARET, SURAKARTA \\ KUSWANTO NURHADI \\ PROGRAM STUDI PERENCANAAN WILAYAH DAN KOTA, FAKULTAS TEKNIK \\ UNIVERSITAS SEBELAS MARET, SURAKARTA \\ ISTI ANDINI \\ PROGRAM STUDI PERENCANAAN WILAYAH DAN KOTA, FAKULTAS TEKNIK \\ UNIVERSITAS SEBELAS MARET, SURAKARTA
}

\begin{abstract}
Accordingly increasing of street vendors especially in Surakarta, City Goverment of Surakarta have been taking policy to relocated street vendors to market. Panggungrejo market serve as a place to relocated street vendors that selling on Ki Hajar Dewantara street. It is taken for maintain the beauty and neatness of city, furthermore to maintaining the continuity of street vendors selling. There are many thing that be supposed in relocated street vendors to market, one of which is a factor of location choice because it will affect the market crowd. Altought the location of Panggungrejo market close to the initial location of street vendors and they're selling almost the same kind of wares, but the market conditions are very quiet and merchants complained of a decrease in turnover, so they chose to sell elsewhere. The question in this research is how the site selection factors influence the effectiveness Panggungrejo Market. The method in this research is deductive-quantitative. The analysis used in this study consisted of descriptive analysis is descriptive narrative and descriptive eksplanatif, as well as multiple regression statistical analysis. Results from this research that despite support for the crowded market place, but the condition of Panggungrejo market is still not effective. There are only three of the nine site selection factors that influence the inefficiencies of Panggungrejo market that are competitors, visibility and market facilities. Therefore, ineffectiveness of Panggungrejo market may also be influenced by other factors.
\end{abstract}

Keywords: Market, Relocation, Effectiveness, Site Selection Factors

\section{PENDAHULUAN}

Pertumbuhan penduduk yang terus meningkat setiap tahunnya ditambah dengan banyaknya kaum migran ke kota yang tidak diimbangi dengan perluasan lapangan kerja formal menyebabkan ketersediaan lapangan pekerjaan menjadi semakin terbatas. Hal tersebut mendorong munculnya sektor informal, salah satunya yaitu Pedagang Kaki Lima (PKL).

Keberadaan PKL di Kota Surakarta jumlahnya cenderung meningkat dari tahun ke tahun. Mereka menempati ruang-ruang publik antara lain taman, trotoar, lahan kosong, dan pinggir jalan sehingga hal tersebut menimbulkan kemacetan, kekumuhan, dan kesemrawutan. Oleh karena itu, Pemkot Surakarta mulai gencar dalam melakukan penertiban PKL antara lain dengan relokasi, shelterisasi, tendanisasi, atau gerobakisasi guna mengembalikan fungsi ruang-ruang publik dan menjaga ketertiban serta keindahan wajah kota. Salah satu upaya yang diambil Pemkot Surakarta dalam menertibkan PKL yaitu merelokasi para PKL ke pasar. Selain menjaga ketertiban dan keindahan kota, pemindahan PKL ke pasar juga bertujuan agar keberlanjutan aktivitas perdagangan para PKL tetap dapat berjalan dengan baik meskipun mereka telah dipindahkan.

Namun, dibalik keberhasilan pelaksanaan relokasi PKL ke pasar di Kota Surakarta, terdapat sejumlah persoalan yang timbul setelah pelaksanaan relokasi antara lain sepinya lokasi pasar yang menjadi tempat relokasi. Hal ini menyebabkan aktivitas 
jual-beli tidak dapat berjalan dengan baik bahkan mematikan usaha berjualan para pedagang. Kondisi tersebut dapat dijumpai di Pasar Panggungrejo yang dijadikan sebagai salah satu tempat relokasi PKL yang berada di sepanjang Jalan Ki Hajar Dewantara (belakang kampus UNS) yang kondisinya justru sangat sepi.

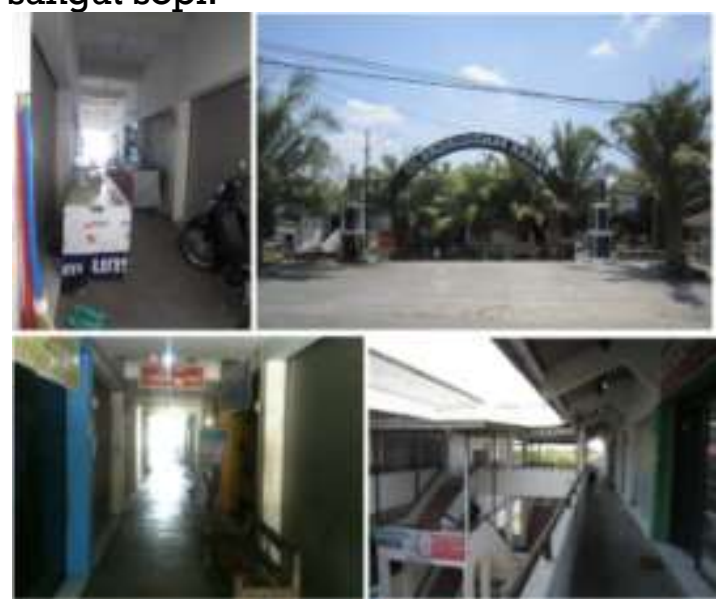

Gambar 1 Kondisi Eksisting Pasar Panggungrejo Sumber: Dokumentasi Yohanita, 2015

Pasar Panggungrejo sebenarnya memiliki karakteristik lokasi yang tidak jauh berbeda dengan lokasi awal PKL berjualan dengan jenis barang dan jasa yang ditawarkan pun hampir sama. Namun meskipun demikian, pada kenyataannya hal tersebut belum mampu membuat Pasar Panggungrejo ramai dikunjungi pembeli. Hal ini telah menyebabkan sebagian besar pedagang memilih untuk tidak berjualan di sana dan lebih memilih untuk kembali berjualan di tempat lain yang lebih strategis.

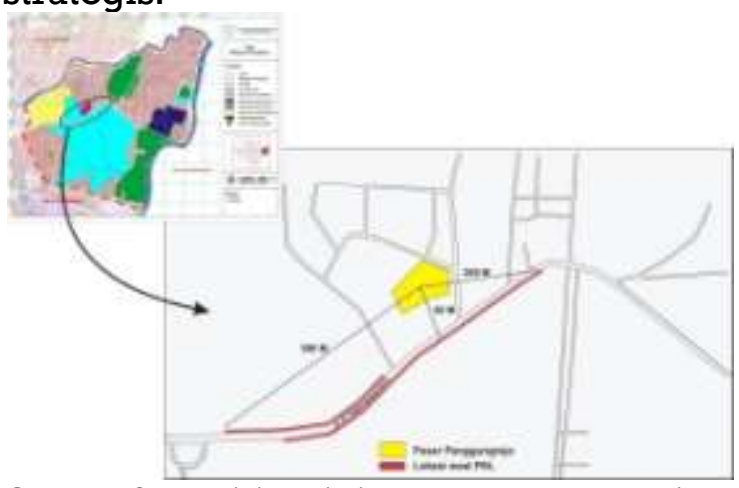

Gambar 2 Kondisi Eksisting Pasar Panggungrejo Sumber: Dokumentasi Yohanita, 2015

Oleh karena itu, dalam penelitian ini didapatkan rumusan masalah yaitu bagaimana pengaruh faktor pemilihan lokasi terhadap efektivitas Pasar Panggungrejo?

\section{METODE PENELITIAN}

Penelitian ini merupakan penelitian deskriptif yang menggunakan pendekatan deduktif, dimana dalam menjawab rumusan masalah digunakan teori yang ada. Sehingga dari teori yang dijadikan sebagai batasan dan perumusan variabel-variabel yang nantinya akan mengarahkan penelitian ini agar tetap sesuai dengan tujuan dan sasaran, serta lebih mempermudah dalam menentukan batsan data apa saja yang akan digunakan.

Pengumpulan data dalam penelitian ini menggunakan teknik pengumpulan data primer yang meliputi observasi lapangan, wawancara, dan kuisioner. Sedangkan pengumpulan data sekunder menggunakan studi literatur/ dokumen dari instansi-instansi terkait.

Penelitian ini bertujuan untuk mengkaji bagaimana pengaruh faktor pemilihan lokasi terhadap efektivitas Pasar Panggungrejo. Untuk mencapai tujuan tersebut maka dilakukan identifikasi karakteristik lokasi dari Pasar Panggungrejo dan efektivitas Pasar Panggungrejo yang dijabarkan secara deskriptif naratif. Selanjutnya untuk mengetahui pengaruh faktor pemilihan lokasi terhadap efektivitas Pasar Panggungrejo digunakan analisis regresi berganda dan deskriptif eksplanatif.

\section{HASIL DAN PEIMBAHASAN}

\section{Karakteristik Pasar Panggungrejo}

Berdasarkan hasil analisis deskriptif naratif terkait karakteristik faktor pemilihan lokasi dari Pasar Panggungrejo, maka dapat dilihat bahwa kondisi lokasi Pasar Panggungrejo berdasarkan faktor-faktor pemilihan lokasi yaitu sebagai berikut:

Tabel 1 Kondisi Faktor Pemilihan Lokasi Dari Pasar Panggungrejo

\begin{tabular}{|c|c|}
\hline $\begin{array}{c}\text { SUB } \\
\text { VARIABEL }\end{array}$ & HASIL \\
\hline Aksesibilitas & $\begin{array}{l}\text { Aksesibilitas menuju Pasar } \\
\text { Panggungrejo baik karena dapat } \\
\text { diakses dengan angkutan umum, } \\
\text { kendaraan pribadi maupun pejalan } \\
\text { kaki. }\end{array}$ \\
\hline $\begin{array}{l}\text { Aktivitas } \\
\text { Pendukung }\end{array}$ & $\begin{array}{l}\text { Terdapat aktivitas yang dapat } \\
\text { mendukung pasar untuk } \\
\text { berkembang karena berada dekat } \\
\text { dengan perkantoran, permukiman }\end{array}$ \\
\hline
\end{tabular}




\begin{tabular}{|l|l|}
\hline \multicolumn{1}{|c|}{ SUB } \\
VARIABEL & \multicolumn{1}{|c|}{ HASIL } \\
\hline Lokasi & $\begin{array}{l}\text { padat penduduk serta kawasan } \\
\text { pendidikan. }\end{array}$ \\
\hline Pesaing & $\begin{array}{l}\text { janyak pedagang pesaing dengan } \\
\text { jenis dagangan sama yang letaknya } \\
\text { lebih strategis di pinggir jalan dan } \\
\text { nyaman. }\end{array}$ \\
\hline Asal Barang & $\begin{array}{l}\text { Sebagian besar barang dagangan } \\
\text { berasal dari dalam kota Surakarta } \\
\text { sehingga biaya distribusi } \\
\text { terjangkau. }\end{array}$ \\
\hline $\begin{array}{l}\text { Asal } \\
\text { Pedagang }\end{array}$ & $\begin{array}{l}\text { Sekitar 50\% pedagang berasal dari } \\
\text { wilayah sekitar Pasar Panggungrejo } \\
\text { sehingga biaya transportasi menuju } \\
\text { pasar terjangkau. }\end{array}$ \\
\hline $\begin{array}{l}\text { Tanah } \\
\text { Ekspansi }\end{array}$ & $\begin{array}{l}\text { Memiliki lahan kosong yang masih } \\
\text { luas yaitu sekitar setengah dari total } \\
\text { luas lahan yang ada. }\end{array}$ \\
\hline $\begin{array}{l}\text { Pangsa } \\
\text { Pasar }\end{array}$ & $\begin{array}{l}\text { Lokasi pasar berada dekat dengan } \\
\text { konsumen potensial yang meliputi } \\
\text { mahasiswa dan masyarakat. }\end{array}$ \\
\hline Visibilitas & $\begin{array}{l}\text { Letak bangunan pasar lebih rendah } \\
\text { dari jalan yang ada di depannya dan } \\
\text { tidak berada di jalan utama } \\
\text { sehingga kurang dapat terlihat jelas. }\end{array}$ \\
\hline Pasar & $\begin{array}{l}\text { Kondisi fasilitas pasar mengalami } \\
\text { penurunan jika dibandingkan } \\
\text { kondisi awalnya serta terkesan kotor } \\
\text { dan kurang terawat. }\end{array}$ \\
\hline Sumber: $A n a$ sisar
\end{tabular}

Sumber: Analisis Yohanita, 2015

Dari tabel di atas, dapat dilihat bahwa enam dari sembilan faktor pemilihan lokasi yang dimiliki oleh Pasar Panggungrejo tergolong baik untuk mendukung pasar agar berkembang yaitu meliputi segi aksesibilitas, aktivitas pendukung, asal barang, asal pedagang, tanah ekspansi, dan pangsa pasar. Sedangkan faktor pemilihan lokasi dari Pasar Panggungrejo yang tergolong buruk dan dapat menghambat perkembangan pasar yaitu lokasi pesaing, visibilitas, serta fasilitas.

\section{Efektivitas Pasar Panggungrejo}

Berdasarkan hasil analisis deskriptif naratif terkait karakteristik efektivitas dari Pasar Panggungrejo, maka berdasarkan faktor-faktor efektivitas pasar dapat dilihat bahwa efektivitas Pasar Panggungrejo yaitu sebagai berikut:

Tabel 2 Kondisi Efektivitas Pasar Panggungrejo

\begin{tabular}{|c|c|}
\hline $\begin{array}{c}\text { SUB } \\
\text { VARIABEL }\end{array}$ & KETERANGAN \\
\hline $\begin{array}{l}\text { Keramaian } \\
\text { pasar }\end{array}$ & $\begin{array}{l}\text { Lebih dari } 80 \% \text { kios di Pasar } \\
\text { Panggungrejo dalam kondisi } \\
\text { tutup, hanya ada } 29 \text { pedagang } \\
\text { yang berjualan sehingga kondisi }\end{array}$ \\
\hline
\end{tabular}

\begin{tabular}{|c|c|}
\hline $\begin{array}{c}\text { SUB } \\
\text { VARIABEL }\end{array}$ & KETERANGAN \\
\hline & $\begin{array}{l}\text { pasar terlihat sangat sepi. Rata- } \\
\text { rata jumlah konsumen tiap hari di } \\
\text { Pasar panggungrejo meningkat } \\
\text { setiap tahunnya. Meskipun begitu } \\
\text { jumlah tersebut masih sangat } \\
\text { rendah yaitu hanya sekitar } 10 \\
\text { orang/hari. Peningkatan } \\
\text { konsumen didominasi oleh } \\
\text { pedagang makanan, sedangkan } \\
\text { jumlah konsumen dari pedagang } \\
\text { lainnya stagnan dan ada yang } \\
\text { menurun. }\end{array}$ \\
\hline $\begin{array}{l}\text { Tempat } \\
\text { jual-beli }\end{array}$ & $\begin{array}{l}\text { Peningkatan omset penjualan di } \\
\text { Pasar Panggungrejo didominasi } \\
\text { oleh pedagang makanan. Namun, } \\
\text { terdapat pula pedagang yang } \\
\text { omsetnya stagnan dan turun. } \\
\text { Sedangkan omset penjualan } \\
\text { mayoritas pedagang di pasar ini } \\
\text { hanya berkisar Rp } 500.000 / \text { bulan } \\
\text { - Rp } 3.000 .000 / \text { bulan. }\end{array}$ \\
\hline $\begin{array}{l}\text { Tempat } \\
\text { bekerja }\end{array}$ & $\begin{array}{l}\text { Hampir setengah dari pedagang } \\
\text { tidak menggantungkan pekerjaan } \\
\text { utama mereka di Pasar } \\
\text { Panggungrejo mengingat kondisi } \\
\text { pasar yang sepi. Peningkatan } \\
\text { pendapatan hanya dirasakan oleh } \\
\text { beberapa pedagang saja, } \\
\text { sedangkan sebagaian besar } \\
\text { pedagang hanya memperoleh } \\
\text { pendapatan kurang dari Rp } \\
\text { l.000.000. Secara keseluruhan, } \\
\text { pedagang mengaku pendapatan } \\
\text { mereka saat ini jauh lebih rendah } \\
\text { jika dibandingkan dengan } \\
\text { pendapatan mereka saat masih } \\
\text { menjadi PKL. }\end{array}$ \\
\hline $\begin{array}{l}\text { Sumber } \\
\text { pendapatan } \\
\text { daerah }\end{array}$ & $\begin{array}{l}\text { Kontribusi Pasar Panggungrejo } \\
\text { terhadap PAD sektor pasar sangat } \\
\text { kecil. Pada tahun } 2012 \text { sampai } \\
2013 \text { terjadi penurunan } \\
\text { penerimaan dan kontribusinya } \\
\text { terhadap PAD sektor pasar. Pada } \\
\text { tahun } 2014 \text { terjadi peningkatan } \\
\text { penerimaan, namun } \\
\text { kontribusinya tetap sama dari } \\
\text { tahun sebelumnya hanya sebesar } \\
0,18 \% \text { per tahun. }\end{array}$ \\
\hline
\end{tabular}

Kondisi Pasar Panggungrejo dilihat dari aspek efektivitas pasar, dapat diketahui bahwa Pasar Panggungrejo tidak efektif. $\mathrm{Hal}$ ini dikarenakan meskipun jumlah konsumen, omset, serta keuntungan dari sebagian pedagang meningkat setiap tahunnya, namun jumlah tersebut masih rendah. Sehingga meskipun mengalami kenaikan, namun kenaikan tersebut tidak menjadikan Pasar Panggungrejo ramai dan belum mampu memenuhi fungsinya. Selain itu, jumlah tersebut juga masih 
jauh lebih rendah jika dibandingkan dengan para pedagang pesaing. Peningkatan jumlah konsumen, omset, dan keuntungan sebagian besar hanya di alami oleh pedagang yang sama terutama para pedagang makanan.

\section{Pengaruh Faktor Pemilihan Lokasi Terhadap Keramaian Pasar Panggungrejo}

Berdasarkan hasil analisis statistik terkait pengaruh asal pedagang, asal barang, dan jumlah pesaing terhadap intensitas jumlah konsumen di Pasar Panggungrejo dapat diketahui bahwa pesaing yang berpengaruh sangat signifikan terhadap jumlah konsumen yang datang ke Pasar Panggungrejo dengan nilai $R^{2}$ 0,935 dan sig. $(0.000<$ 0,05). Sedangkan sub variabel lainnya yaitu asal pedagang dan asal barang tidak memiliki pengaruh yang signifikan terhadap intensitas jumlah konsumen. Keberadaan para pedagang pesaing yang berjualan di tempat lebih strategis yaitu di sepanjang pinggir jalan-jalan utama dengan menawarkan barang maupun jasa yang biasa menjadi kebutuhan masyarakat sekitar khususnya para mahasiswa memang dapat berpengaruh terhadap jumlah konsumen maupun keramaian Pasar Panggungrejo.

Sedangkan dari hasil analisis deskriptif eksplanatif hanya visibilitas dan fasilitas pasar yang berpengaruh terhadap sepinya kondisi pasar. Meskipun Pasar Panggungrejo memiliki aksesibilitas yang baik, aktivitas sekitar yang mendukung perkembangan pasar, memiliki lahan yang luas, dan memiliki peluang pangsa pasar yang potensial, namun hal tersebut tidak berpengaruh terhadap keramaian dari Pasar Panggungrejo karena keberadaan pedagang pesaing dengan karakteristik dagangan dan lokasi yang sama, serta letak toko mereka yang lebih strategis membuat para konsumen lebih memilih membeli ke tempat tersebut daripada harus masuk ke pasar yang letaknya menurun dan kondisinya sepi serta kurang bersih. Hal inilah yang menyebabkan kondisi Pasar Panggungrejo sepi pengunjung atau konsumen. Sehingga hal tersebut sesuai dengan teori dari (Losch dalam Sjafrizal 2008)bahwa jarak ke lokasi penjual akan berpengaruh terhadap jumlah konsumen yang datang. Dalam hal ini konsumen lebih memilih untuk membeli di pedagang pesaing yang lokasinya lebih dekat dengan tempat tinggal mereka sehingga lebih mudah dijangkau.

\section{Pengaruh Faktor Pemilihan Lokasi Terhadap Omset Pedagang Pasar Panggungrejo}

Omset penjualan menjadi salah satu indikator dari terpenuhinya fungsi pasar sebagai tempat jual-beli karena besar kecilnya omset dapat menandakan banyak sedikitnya barang yang dapat dijual oleh pedagang. Sehingga semakin tinggi intensitas jual-beli pada suatu pasar maka omset dari pedagang juga akan semakin tinggi. Berdasarkan hasil analisis deskriptif naratif, omset penjualan dari sebagian pedagang di Pasar Panggungrejo mengalami kenaikan dari tahun sebelumnya, namun terdapat pula pedagang yang justru omsetnya stagnan atau bahkan terus menurun. Peningkatan omset sebagian besar dialami oleh para pedagang makanan, sedangkan pedagang barang lainnya justru cenderung menurun. Hal ini juga dipengaruhi oleh kondisi pasar yang sepi pengunjung, sehingga tidak sedikit dari para pedagang yang lebih memilih untuk tidak berjualan atau bahkan hingga menjual kiosnya.

Dari hasil analisis deskriptif eksplanatif diketahui bahwa hanya terdapat dua sub variabel yang memiliki pengaruh terhadap omset pedagang di Pasar Panggungrejo yaitu visibilitas dan fasilitas pasar. Sedangkan dari sub variabel lainnya seperti aksesibilitas, aktivitas pendukung, tanah ekspansi, dan pangsa pasar tidak berpengaruh karena meskipun kondisi faktor tersebut seharusnya dapat mendukung peningkatan omset pedagang, namun pada kenyataannya omset pedagang masih stagnan bahkan ada pula yang menurun. Penurunan omset pedagang ini juga merupakan akibat dari kondisi pasar yang sangat sepi, sehingga aktivitas jual-beli tidak dapat berjalan dengan sebagaimana mestinya. Hal 
tersebut dikarenakan para konsumen yang didominasi oleh para mahasiswa lebih tertarik untuk membeli di pedagang pesaing di sepanjang jalan yang tempatnya dapat langsung dijangkau dengan mudah, tidak harus berjalan terlalu jauh dan menaiki tangga. Apalagi harga dan jenis barang yang ditawarkan oleh para pedagang pesaing hampir sama bahkan ada sebagian pedagang pesaing yang menawarkan harga lebih murah dan jenis barang yang lebih bervariasi. Sehingga hal tersebut dapat menjadi daya tarik tersendiri bagi para konsumen untuk datang membeli, dimana itu berakibat pada turunnya omset para pedagang di Pasar Panggungrejo.

Sementara itu, berdasarkan hasil analisis statistik terkait pengaruh asal pedagang, asal barang, dan jumlah pesaing terhadap omset penjualan pedagang di Pasar Panggungrejo dapat diketahui bahwa hanya pesaing yang berpengaruh sangat signifikan terhadap omset penjualan pedagang di Pasar Panggungrejo dengan $\mathrm{R}^{2}$ sebesar 0,592 dan sig. $(0.000<0,05)$. Sedangkan sub variabel lainnya yaitu asal pedagang dan asal barang memiliki nilai $R^{2}$ yang sangat kecil sehingga tidak berpengaruh signifikan terhadap omset penjualan pedagang.

\section{Pengaruh Faktor Pemilihan Lokasi Terhadap Keuntungan Pedagang Pasar Panggungrejo}

Keuntungan dari para pedagang di Pasar Panggungrejo tergantung pada omset yang mereka dapatkan, semakin besar omset yang mereka peroleh maka keuntungan yang akan didapatkan juga akan semakin besar (Chaniago, 1995). Oleh karena itu, dalam pembahasan ini juga akan berkaitan dengan pembahasan sebelumnya di atas, yang terkait dengan omset pedagang di Pasar Panggungrejo. Sama seperti pengaruh dari sub variabel faktor pemilihan lokasi terhadap omset pedagang pada analisis deskriptif eksplanatif sebelumnya, dari keenam sub variabel yang dianalisis secara eksplanasi hanya terdapat dua sub variabel yang berpengaruh yaitu visibilitas pasar dan fasilitas pasar. $\mathrm{Hal}$ ini dikarenakan keuntungan yang diterima pedagang bergantung pada omset penjualan mereka. Sehingga faktor pemilihan lokasi yang berpengaruh terhadap omset pedagang juga akan berpengaruh terhadap keuntungan yang pedagang dapatkan.

Sedangkan berdasarkan hasil analisis statistik terkait pengaruh asal pedagang, asal barang, asal konsumen, dan jumlah pesaing terhadap keuntungan pedagang di Pasar Panggungrejo dapat diketahui bahwa hanya pesaing yang berpengaruh sangat signifikan terhadap keuntungan pedagang di Pasar Panggungrejo dengan $\mathrm{R}^{2}$ sbesar 0,406 dan sig. $(0,002<$ $0,05)$. Sedangkan ketiga sub variabel lainnya yaitu asal pedagang, asal barang, dan asal konsumen tidak memiliki pengaruh yang signifikan terhadap keuntungan pedagang karena hanya memiliki nilai $R^{2}$ sangat kecil yaitu masing-masing 0,001 untuk asal pedagang, 0,038 untuk asal barang, dan 0,064 untuk asal konsumen. Namun dari analisis regresi ini, didapat Adjusted $R$ Square sebesar 0,122 atau berarti model ini hanya mampu menjelaskan sekitar $12,2 \%$ pengaruh faktor lokasi tersebut terhadap keuntungan pedagang, sehingga ada indikasi bahwa keuntungan pedagang lebih dipengaruhi oleh faktor lain.

\section{Pengaruh Faktor Pemilihan Lokasi Terhadap Kontribusi Penerimaan Pasar Panggungrejo Bagi PAD Sektor Pasar Kota Surakarta}

Pasar merupakan salah satu sektor yang dapat menjadi sumber pendapatan daerah. Begitu pula di Kota Surakarta yang memiliki sekitar 43 pasar tradisional yang turut berkontribusi sebagai salah satu sumber PAD. Salah satunya adalah Pasar Panggungrejo, penerimaan Pasar Panggungrejo berasal dari pembayaran retribusi, pembayaran listrik pasar, sewa kios, dan lain-lain. Besarnya penerimaan Pasar Panggungrejo ini tergantung pada besaran retribusi dan banyaknya pedagang atau kios yang buka di pasar tersebut. Semakin banyak pedagang yang berjualan di suatu pasar maka akan 
semakin besar pula penerimaan pasar yang didapatkan. Dengan adanya karakteristik lokasi yang mendukung maka akan meningkatkan minat masyarakat untuk berjualan di lokasi tersebut. Meskipun Pasar Panggungrejo terletak di kawasan yang potensial untuk perkembangan pasar, namun kondisi di lapangan justru sebaliknya yaitu pasar terlihat sangat sepi. Pada pembahasan ini tidak ada sub variabel yang dianalisis secara statistik.

Sementara itu, berdasarkan analisis deskriptif eksplanatif meskipun terdapat beberapa faktor yang berpengaruh terhadap kontribusi Pasar Panggungrejo bagi PAD, namun jika dilihat sebenarnya faktor pemilihan lokasi tidak berpengaruh langsung terhadap kontribusi Pasar Panggungrejo bangi PAD sektor pasar. Kontribusi pasar terhadap PAD lebih dipengaruhi pada penerimaan pasar lain di Surakarta. Meskipun dari penerimaan Pasar Panggungrejo meningkat pada beberapa tahun, namun kontribusinya justru menurun dan stagnan. Hal ini menunjukkan bahwa adanya indikasi penerimaan dari pasar lain di Kota Surakarta mengalami peningkatan yang lebih besar daripada penerimaan Pasar Panggungrejo. Sehingga dapat dikatakan bahwa terdapat faktor lain yang lebih berpengaruh terhadap kontribusi Pasar Panggungrejo.

\section{Pengaruh Faktor Pemilihan Lokasi Terhadap Efektivitas Pasar Panggungrejo}

Setelah dijabarkan pengaruh dari faktor pemilihan lokasi terhadap masingmasing sub variabel efektivitas Pasar Panggungrejo seperti di atas, selanjutnya akan digeneralisasikan pengaruh dari analisis regresi dan analisis eksplanatif sehingga mendapatkan hasil bahwa hanya terdapat tiga sub variabel aspek pemilihan lokasi yang berpengaruh yaitu pesaing, visibilitas, dan fasilitas pasar. Sedangkan enam sub variabel yang lainnya tidak berpengaruh terhadap efektivitas Pasar Panggungrejo(Tabel 3 dapat dilihat pada lampiran di halaman 7).
Sementara itu, jika dilihat pengaruh antar sub variabel dari aspek faktor pemilihan lokasi terhadap aspek efektivitas Pasar Panggungrejo yang didasarkan pada analisis regresi dan analisis eksplanasi (Tabel 4 dapat dilihat pada lampiran di halaman 8).

\section{KESIMPULAN}

Jika dilihat dari faktor pemilihan lokasinya yang meliputi aksesibilitas, aktivitas pendukung, dan pangsa pasar, Pasar Panggungrejo memiliki karakteristik lokasi yang baik untuk mendukung pasar tersebut berkembang. Namun, terdapat pula beberapa faktor yang kurang baik seperti keberadaan pesaing, visibilitas, dan fasilitas pasar yang dapat menghambat perkembangan pasar. Sedangkan dari indikator efektivitas dalam penelitian ini yang meliputi keramaian pasar dan pemenuhan fungsi pasar seperti tempat jual-beli, tempat bekerja, dan sumber PAD dapat disimpulkan bahwa Pasar Panggungrejo belum dapat dikatakan efektif, meskipun indikator-indikator tersebut mengalami peningkatan yang relatif kecil setiap tahunnya.

Keberadaan pedagang pesaing menjadi faktor pemilihan lokasi yang berpengaruh kuat terhadap terhadap ketidakefektifan Pasar Panggungrejo jika dilihat dari keramaian pasar, serta berpengaruh sedang terhadap omset pedagang.

Secara keseluruhan, faktor pemilihan lokasi tidak berpengaruh terhadap efektvitas Pasar Panggungrejo karena hanya tiga dari sembilan sub variabel pemilihan lokasi yang berpengaruh terhadap ketidakefektivan Pasar Panggungrejo. Ketidakefektifan pasar ini lebih dipengaruhi oleh faktor lain.

\section{DAFTAR PUSTAKA}

A.Arifinal Chaniago, dkk. 1995. “Ekonomi 2". Bandung: Angkasa.

Sjafrizal. 2008. "Ekonomi Regional: Teori Dan Aplikasi". Padang: Baduose Media. 


\section{LAMPIRAN}

Tabel 3 Pengaruh Faktor Pemilihan Lokasi Terhadap Efektivitas Pasar Panggungrejo

\begin{tabular}{|c|c|c|c|c|}
\hline $\begin{array}{l}\text { Hasil } \\
\text { Analisis } \\
\text { Regresi } \\
\text { Hasil Analisis } \\
\text { Elksplanatif }\end{array}$ & $0-0,33$ & $0,34-0,66$ & $0,67-1$ & Non-Regresi \\
\hline Pengaruh I & - & - & $\begin{array}{l}\text { Keberadaaan pesaing } \\
\text { berpengaruh kuat } \\
\text { terhadap keramaian di } \\
\text { Pasar Panggungrejo. Hal } \\
\text { ini dikarenkan para } \\
\text { pesaing juga } \\
\text { menawarkan jenis } \\
\text { barang yang lebih } \\
\text { bervariasi dengan harga } \\
\text { yang kompetitif, serta } \\
\text { berada lebih strategis di } \\
\text { pinggir jalan. Sehingga } \\
\text { konsumen lebih tertarik } \\
\text { untuk membeli ke } \\
\text { pedagang pesaing. }\end{array}$ & $\begin{array}{l}\text { Keberadaan pesaing, visibilitas, } \\
\text { dan fasilitas pasar berpengaruh } \\
\text { sedang terhadap omset penjualan } \\
\text { dan keramaian pasar karena para } \\
\text { konsumen lebih cenderung } \\
\text { membeli ke pedagang pesaing } \\
\text { dari pada pedagang di Pasar } \\
\text { Panggungrejo. }\end{array}$ \\
\hline Pengaruh II & $\begin{array}{l}\text { Berdasarkan } \\
\text { pembahasan } \\
\text { sebelumnya, } \\
\text { diketahui bahwa } \\
\text { asal barang, asal } \\
\text { pedagang, dan } \\
\text { asal konsumen, } \\
\text { berpengaruh } \\
\text { lemah terhadap } \\
\text { keramaian, } \\
\text { omset, dan } \\
\text { keuntungan } \\
\text { pedagang. }\end{array}$ & - & - & $\begin{array}{l}\text { Aksesibilitas, aktivitas pendukung, } \\
\text { tanah ekspansi, pangsa pasar tidak } \\
\text { berpengaruh terhadap keramaian, } \\
\text { omset, keuntungan, maupun } \\
\text { kontribusi terhadap PAD dari } \\
\text { Pasar Panggungrejo. Hal ini } \\
\text { dikarenakan meskipun faktor- } \\
\text { faktor tersebut mendukung pasar } \\
\text { untuk berkembang, namun pada } \\
\text { kenyataannya pasar masih tidak } \\
\text { efektif. }\end{array}$ \\
\hline Pengaruh III & - & - & - & - \\
\hline Pengaruh IV & - & - & - & $\begin{array}{l}\text { Pesaing, visibilitas, dan fasilitas } \\
\text { pasar berpengaruh lemah } \\
\text { terhadap kontribusi Pasar } \\
\text { Panggungrejo bagi PAD karena } \\
\text { meskipun berpengaruh pada } \\
\text { sedikitnya jumlah pedagang yang } \\
\text { mau berjualan sehingga } \\
\text { penerimaan pasar stagnan, namun } \\
\text { juga dipengaruhi oleh besaran } \\
\text { kontribusi dari pasar lain. } \\
\text { Sementara itu, pesaing, visibilitas, } \\
\text { dan fasilitas berpengaruh lemah } \\
\text { terhadap keuntungan pedagang } \\
\text { karena ketiganya tidak } \\
\text { berpengaruh langsung. }\end{array}$ \\
\hline
\end{tabular}

Sumber: Analisis Yohanita, 2015

Tabel 4 Pengaruh Antar Sub Variabel Aspek Faktor Pemilihan Lokasi Terhadap Aspek Efektivitas Pasar Panggungrejo

\begin{tabular}{|c|c|c|c|c|}
\hline $\begin{array}{l}\text { Efektivitas } \\
\text { Pasar } \\
\begin{array}{l}\text { Pemilihan } \\
\text { Lokasi }\end{array}\end{array}$ & Keramaian Pasar & Tempat Jual-Beli & Tempat Bekerja & Sumber PAD \\
\hline \multicolumn{1}{|c|}{ Aksesibilitas } & Tidak Berpengaruh & Tidak Berpengaruh & Tidak Berpengaruh & Tidak Berpengaruh \\
\hline
\end{tabular}


Region, Volume 6, No. 2, Juli 2015

\begin{tabular}{|c|c|c|c|c|}
\hline $\begin{array}{c}\text { Efektivitas } \\
\text { Faktor } \\
\text { Pemilihan } \\
\text { Lokasi }\end{array}$ & Keramaian Pasar & Tempat Jual-Beli & Tempat Belkerja & Sumber PAD \\
\hline $\begin{array}{c}\text { Aktivitas } \\
\text { Pendukung }\end{array}$ & Tidak Berpengaruh & Tidak Berpengaruh & Tidak Berpengaruh & Tidak Berpengaruh \\
\hline Pesaing & $\begin{array}{c}\text { Berpengaruh Kuat } \\
\left(\mathrm{R}^{2}=0,935\right)\end{array}$ & $\begin{array}{c}\text { Berpengaruh Sedang } \\
\left(\mathrm{R}^{2}=0,592\right)\end{array}$ & Berpengaruh Lemah & Berpengaruh Lemah \\
\hline Asal Barang & Tidak Berpengaruh & Berpengaruh Lemah & Berpengaruh Lemah & Berpengaruh Lemah \\
\hline Asal Pedagang & Berpengaruh Lemah & Berpengaruh Lemah & Berpengaruh Lemah & Berpengaruh Lemah \\
\hline Tanah Ekspansi & Tidak Berpengaruh & Tidak Berpengaruh & Tidak Berpengaruh & Tidak Berpengaruh \\
\hline Pangsa Pasar & Tidak Berpengaruh & Tidak Berpengaruh & Tidak Berpengaruh & Tidak Berpengaruh \\
\hline Visibilitas Pasar & Berpengaruh Sedang & Berpengaruh Sedang & Berpengaruh Lemah & Berpengaruh Lemah \\
\hline Fasilitas Pasar & Berpengaruh Sedang & Berpengaruh Sedang & Berpengaruh Lemah & Berpengaruh Lemah \\
\hline
\end{tabular}

Sumber: Analisis Yohanita, 2015 